\title{
Sex effects and phenotypic correlation among growth traits in America standard Chinchilla rabbits in Southwest Nigeria
}

\author{
Adeoye, A. A.
}

Department of Animal Production and Health,

Ondo State University of Science and Technology, Okitipupa, Nigeria

*Corresponding author: adeomoh@yahoo.com;+2348138273174

\section{Abstract}

Data on body weight and linear body measurements collected from 101 America Standard Chinchilla rabbits comprised of 62 females and 39 males at eight weeks were used to determine the effect of sex and phenotypic correlations among the growth traits. The estimates were statistically $(p<0.05)$ higher in the female compared with male in virtually all the traits considered except in the fore arm length. The values for body weight, body length, ear length, tail length, fore arm length, heart girth and abdominal circumference for females were $1.19 \mathrm{~kg}, 31.97 \mathrm{~cm}, 10.67 \mathrm{~cm}, 9.89 \mathrm{~cm}, 15.61 \mathrm{~cm}, 21.61 \mathrm{~cm}$ and $23.75 \mathrm{~cm}$, respectively while the corresponding values for males were $0.88 \mathrm{~kg}, 28.00 \mathrm{~cm}, 10.44 \mathrm{~cm}, 8.95 \mathrm{~cm}, 14.74$ $\mathrm{cm}, 19.62 \mathrm{~cm}$ and $21.67 \mathrm{~cm}$. The correlation between body weight and the linear body measurements was positively significant $(p<0.05$ and $p<0.001)$ and ranged between 0.301 and 0.951 in males while in females positive and significant correlations were found between body weight and body length (0.831), tail length (0.184), heart girth (0.788) and abdominal circumference (0.719). The correlations among the linear body measurements in the males ranged between 0.108 and 0.951 while in females it ranged between -0.235 and 0.681 . The positive relationships between body weight and linear body measurements can be used as basis for body weight selection in both male and female rabbits

Keywords: Rabbits, sex, growth traits, phenotypic correlation

\section{Introduction}

Rabbits are small mammals in the family Leporidae of the order Lagomorpha. There are about 305 breeds of domestic rabbit. Best known for being prolific, rabbits are also herbivores which efficiently convert fodder to food. The only limiting factor reported to be affecting growth and productivity of rabbits in tropical and arid climates according to McNitt et al. (2000) is calorie stress associated with high ambient temperature. Rabbit meat provides a cheap source of meat which is characterized by a high protein and low fat cholesterol content (Aduku and Olukosi, 1990). Rabbits have the potentials to supply good and high quality animal proteins, and are comparable to domestic chickens which have short gestation and generation interval, highly prolific, lack of taboos to its production and consumption, and can subsist on domestic waste and succulent leaves. In the tropics where there is stiff competition for grains and legumes between man and animals, rabbits can conveniently be reared in small or large scale since they can survive on forages and agricultural by-products not consumed by man. There are genetic and environmental factors affecting the post weaning growth rate of rabbits, and these include breed (Lukefahr et al., 1983; Ozimba and Lukefahr, 1991), sex (Afifi et al., 2000), season or month (Afifi and Emara, 1990). Oke et al. (2010) and Isaac et al. (2010) also observed significant differences in growth traits among breeds of rabbits. The relationships existing among growth traits provide useful information on performance, productivity and carcass characteristics of animals. These traits are less subjected to short term changes as is body weight and allow 


\section{Sex effects and phenotypic correlation among growth traits}

comparisons of growth in different part of the body (Russell, 1975). Besides, body weight and linear body measurements of meat animals have been found useful in quantifying body size and shape (Ibe, 1989). The objective of this study was to provide information on the influence of sex on growth traits and correlations among them in America Chinchilla rabbits in south-west Nigeria.

\section{Materials and methods}

One hundred and one 8 wk old rabbits at comprising 62 females and 39 males were used for this study in a farm located in Ibadan, Oyo State. The animals were housed in individual cage in a wellventilated rabbit building. The cages were large enough for free movement. Each cage was fitted with a stainless feeder and drinker. The rabbits were fed with pelleted feed and clean drinking water. Feed was given daily. Feeders and drinkers were cleaned daily. The cages were cleaned every day from food particles, faeces and other wastes. Data on body weight (BW) in $\mathrm{kg}$ using a weighing scale and five other linear body measurements in $\mathrm{cm}$ were taken using measuring tape as follows:

Body Length (BL) was measured as the diagonal distance from the point of the shoulder to the pin bone; Tail Length (TL) was measured from the base of the tail to the tip; Ear Length (EL) was the distance from the base of attachment of the ear to the head to the tip of the ear; Fore arm Length (FL) was recorded as the length from the attachment of the fore arm; Heart Girth (HG) was measured as body circumference just behind the fore leg while Abdominal Circumference (AC) was measured as body circumference at the middle of the animal. The data collected were subjected to analysis of variance to determine the summary statistics and sex effect on the growth traits using SAS (2001). Pearson correlation was used to determine the correlation coefficients among the traits on sex basis.

\section{Results}

Table 1 shows the summary statistics of bod weight and linear body measurements of America Chinchilla rabbits at 8 weeks on the basis of sex. Higher coefficients of variations were observed in the body weight of male (25.86) and female (16.21) while the least values were observed in abdominal circumference (4.52) in female and heart girth (6.47) in male.

Table 1: Summary statistics of body weight and linear measurements in chinchilla rabbits

\begin{tabular}{llllllll}
\hline SEX & VARIABLES & MEANS & SD & N & MIN & MAX & CV \\
\hline F & BW & $1.19 \pm 0.02$ & 0.19 & 61 & 0.80 & 1.50 & 16.21 \\
& BL & $31.97 \pm 0.25$ & 1.98 & 61 & 28.00 & 34.00 & 6.20 \\
& EL & $10.67 \pm 0.13$ & 1.05 & 61 & 9.00 & 13.00 & 9.82 \\
& TL & $9.89 \pm 0.19$ & 1.47 & 61 & 8.00 & 13.00 & 14.87 \\
& FL & $15.61 \pm 0.14$ & 1.07 & 61 & 14.00 & 17.00 & 6.85 \\
& HG & $21.61 \pm 0.17$ & 1.35 & 61 & 19.00 & 23.00 & 6.23 \\
& AC & $23.75 \pm 0.14$ & 1.07 & 61 & 22.00 & 25.00 & 4.52 \\
\hline M & BW & $0.88 \pm 0.04$ & 0.23 & 39 & 0.70 & 1.40 & 25.86 \\
& BL & $28.00 \pm 0.37$ & 2.31 & 39 & 25.00 & 33.00 & 8.23 \\
& EL & $10.44 \pm 0.25$ & 1.57 & 39 & 9.00 & 14.00 & 15.08 \\
& TL & $8.95 \pm 0.14$ & 0.85 & 39 & 8.00 & 10.00 & 9.49 \\
& FL & $14.74 \pm 0.17$ & 1.04 & 39 & 13.00 & 17.00 & 7.08 \\
& HG & $19.62 \pm 0.20$ & 1.27 & 39 & 18.00 & 22.00 & 6.47 \\
& AC & $21.67 \pm 0.29$ & 1.81 & 39 & 20.00 & 25.00 & 8.36 \\
\hline
\end{tabular}

Bw-body weight; Bl-boy length; El-ear length Tl-tail length; Fl-fore arm length; Hg-heart girth; Ac-abdominal circumference 


\section{Adeoye}

Table 2 shows the effect of sex on the body weight and the linear body measurements. The estimates were statistically $(\mathrm{p}<0.05)$ higher in the female compare with male in virtually all the traits considered except in fore arm length. The values for body weight, body length, ear length, tail length, fore arm length, heart girth and abdominal circumference for female were $1.19 \pm 0.02$, $31.97 \pm 0.25,10.67 \pm 0.13,9.89 \pm 0.19$, $15.61 \pm 0.14,21.61 \pm 0.17$ and $23.75 \pm 0.14$, respectively while the corresponding values for male were $0.88 \pm 0.04,28.00 \pm$ $0.37,10.44 \pm 0.25,8.95 \pm 0.14,14.74 \pm$ $0.17,19.62 \pm 0.20$ and $21.67 \pm 0.29$.

Table 2: Effect of sex on body weight and linear body measurement at eight weeks in chinchilla rabbits

\begin{tabular}{llll}
\hline Variables & Male & Female & Overall \\
\hline BW & $0.88^{\mathrm{b}} \pm 0.04$ & $1.19^{\mathrm{a}} \pm 0.02$ & $1.07 \pm 0.03$ \\
BL & $28.00^{\mathrm{b}} \pm 0.37$ & $31.97^{\mathrm{a}} \pm 0.25$ & $30.42 \pm 0.29$ \\
EL & $10.44^{\mathrm{a}} \pm 0.25$ & $10.67^{\mathrm{a}} \pm 0.13$ & $10.58 \pm 0.13$ \\
TL & $8.95^{\mathrm{b}} \pm 0.14$ & $9.89^{\mathrm{a}} \pm 0.19$ & $9.52 \pm 0.13$ \\
FL & $14.74^{\mathrm{b}} \pm 0.17$ & $15.61^{\mathrm{a}} \pm 0.14$ & $15.27 \pm 0.11$ \\
HG & $19.62^{\mathrm{b}} \pm 0.20$ & $21.61^{\mathrm{a}} \pm 0.17$ & $20.83 \pm 0.16$ \\
AC & $21.67^{\mathrm{b}} \pm 0.29$ & $23.75^{\mathrm{a}} \pm 0.14$ & $22.94 \pm 0.17$ \\
\hline
\end{tabular}

Bw-body weight; Bl-boy length; El-ear length Tl-tail length; Fl-fore arm length; Hg-heart girth; Ac-abdominal circumference

The correlation coefficients among the body weight and linear measurements is shown in Table 3. The upper diagonal indicates the correlations for male, while the lower diagonal is for female. The correlations between body weight and the linear body measurements were positive, significant $(p<0.05$ and $p<0.001)$ and range between
0.301 and 0.951 in male while in female, positive and significant correlations were found between body weight and body length (0.831), tail length (0.184), heart girth (0.788) and abdominal circumference (0.719). The correlations among the body linear measurements in the males ranged between 0.108 and 0.951 while in females it ranged between -0.235 and 0.681 .

Table 3: Phenotypic correlation among the body weight and linearbody measurements in Chinchilla

\begin{tabular}{llllllll}
\hline & BW & BL & EL & TL & FL & HG & AC \\
\hline BW & 1.000 & $0.951^{* * *}$ & $0.884^{* * *}$ & $0.301^{*}$ & $0.930^{* * *}$ & $0.648^{* * *}$ & $0.851^{* * *}$ \\
BL & $0.831 * * *$ & 1.000 & $0.892^{* * *}$ & 0.108 & $0.874^{* * *}$ & $0.674^{* * *}$ & $0.851^{* * *}$ \\
EL & -0.156 & 0.163 & 1.000 & $0.411^{* *}$ & $0.895^{* * *}$ & $0.748^{* * *}$ & $0.856^{* * *}$ \\
TL & 0.184 & $0.530^{* *}$ & $0.483^{* *}$ & 1.000 & $0.341^{*}$ & $0.396^{*}$ & 0.288 \\
FL & -0.011 & $0.505^{* *}$ & $0.627^{* * *}$ & $0.681^{* * *}$ & 1.000 & $0.638^{* * *}$ & $0.816^{* * *}$ \\
HG & $0.788^{* * *}$ & $0.570^{* *}$ & -0.046 & 0.086 & -0.086 & 1.000 & $0.870^{* * *}$ \\
AC & $0.719^{* * *}$ & $0.489^{* *}$ & -0.235 & 0.024 & -0.216 & $0.877^{* * *}$ & 1.000 \\
\hline
\end{tabular}

Bw-body weight; Bl-boy length; El-ear length Tl-tail length; Fl-fore arm length; Hg-heart girth; Ac-abdominal circumference

\section{Discussion}

The significant sex effect $(\mathrm{p}<0.05)$ observed in virtually all the variables considered in this study was in favour of female which indicates sexual dimorphism. This is in line with the observation of Ologbose et al. (2017) who reported that at eight weeks female New Zealand White, Dutch and their crosses were statistically higher in body weight and linear body measurements compared to the males. The body weight of $1.19 \mathrm{~kg}$ observed for female in this study is higher to what was reported $(856.25 \mathrm{~g}$ and $544.64 \mathrm{~g}$ ) for Dutch and New Zealand White female rabbit by Ologbose et al. (2017). This could be attributed to 
Sex effects and phenotypic correlation among growth traits

differences in breed. Similar trend was observed in male body weight and all other variables considered. The overall abdominal circumference $(22.94 \mathrm{~cm})$ observed in this study is lower to the report of Hassan et al. (2012) at age twenty weeks $(23.59 \mathrm{~cm})$. The overall estimates for all the parameters considered are lower to the reports of Ifeanyichukwu (2013) for the same breed. The phenotypic correlations between body weight and the linear body measurements in males and females are all significant, positive and moderate to high correlated which indicate pleiotropy i.e. improvement in any of the variables will lead to improvement in the body weight. This observation is similar to the report of Hassan et al. (2012) and Orheruata et al. (2006).

\section{Conclusion}

The significant effect of sex on the growth traits indicated sexual dimorphism and the positive correlations between bodyweight and some of the linear body measurements indicate pleiotropy which means that increament in those linear measurements will lead to increment in the bodyweight, thus principle of correlation could be use as basis for genetic improvement of live bodyweight.

\section{References}

Aduku, A. O. and Olukosi, J. O. 1990. Rabbit management in the tropics production, processing, utilization, marketing, economic practical training, research and future prospects. Living Book Series, G. U. Publications, Abuja.

Afifi, E. A. and Emara, M. E. 1990. Breed group and environmental factors influencing post weaning daily gain in weight of purebred and crossbred rabbits. J. Applied Rabbit Res. 13: 114-118
Afifi, E. A., Abd El-Ghany, A. and Ahmed, E. G. 2000. Reproductive profile of New Zealand White and Californian rabbits under semi-arid environmental conditions. Egypt Poul. Sci.20(1): 145-155.

Hassan, H. E., Elamin, K. M., Yousif, I. A., Musa, A. M. and Elkhairey, M. A. 2012. Evaluation of Body Weight and some Morphometric Traits at Various Ages in Local Rabbits of Sudan. J. Anim Sci Adv 2012, 2(4): 407-415

IBE, S. N. 1989. Measurement of size and confirmation in commercial broilers. J. Anim. Breed and Genet., 1989, vol. 106, p. 461-469.

Isaac, L. J., Eko, P. M., Ekpo J. S., Ekanem, E. and Essien, G. B. 2010. Effect of breed on performance of rabbit in feed", Proc. $35^{\text {th }}$ conf., Nigerian Soc. for Animal Production, 14-17, March 2010, University of Ibadan. pp.1819.

Ifeanyichukwu, U. 2013. Prediction of Body Weight in Rabbits using Principal Component Factor Scores in Multiple Linear Regression Model. Bioflex society, Volume 3, Issue 1. P1-6.

Lukefahr, S. D., Hohenboken, W. D. Cheeke, P. R. and Patton, N. M. 1983. Characterization of straight bred and crossbred rabbits for milk production and associative traits. $J$. Anim. Sci. 57: 1100.

McNitt, J. I., Patton, N. M., Lukefahr, S. D. and Cheeke, P. R. 2000. Rabbit Production. Interstate Publishers ( $7^{\text {th }}$ edition) Danville, IL. p:493.

Oke, U. K., Herbert, U., Nwichi, C., Onyiro, O. M. and Okocha, C. N. 2010. Effect of breed of sire on growth performance of crossbred rabbits in a humid tropical 


\section{Adeoye}

environment. Proc. $35^{\text {th }}$ conf., Nigerian Soc. for Animal Production. 14-17, March 2010, University of Ibadan. pp:15-17.

Ologbose, F. I., Ajayi, F. O. and Agaviezor, B. 2017. Effect of Breeds, Sex and Age on Interrelationship between Body Weight and Linear Body Measurement in Rabbits. $J$ Fisheries Livest Prod 5: 250 doi: 10.4172/2332-2608.1000250

Orheruata, A. M., Oyedeji, J. O., Omoyakhi, M. and Ofuoma, F. 2006. post-weaning body morphology and carcass characteristics of rabbits in the humid rainforest zone of Nigeria. Int. J. Agric. Rural Dev. 7 (2) 4047.
Ozimba, C. E. and Lukefahr, S. D. 1991. Comparison of rabbit breed types for post weaning litter growth, feed efficiency and survival performance traits. J. Anim. Sci. 69: 34943500 .

Statistical Analysis System SAS, 2001. SAS Users Guide. Statistics, $8^{\text {th }}$ edition, SAS Institute Cary, NC, USA.

Received: $4^{\text {th }}$ March, 2019

Accepted: $10^{\text {th }}$ June, 2019 